
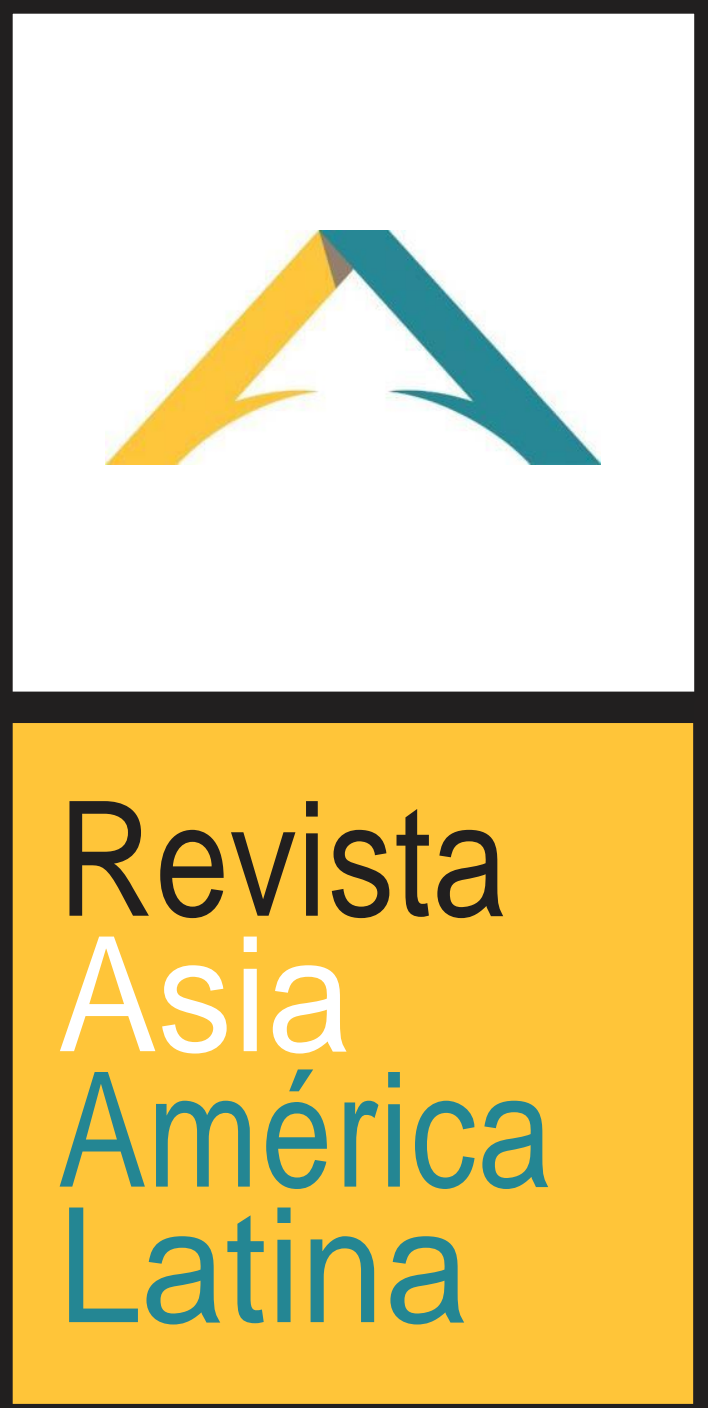

ISSN 2524-9347

Grupo de Estudios sobre Asia y América Latina Instituto de Estudios de América Latina y el Caribe Universidad de Buenos Aires

EU

DE BA 


\section{THE ASEAN WAY ON THE INDO-PACIFIC AMONG OTHER WAYS}

\section{Sebastián Sterzer}

sterzersebastian@gmail.com

Universidad Nacional de Luján

\section{Introduction}

The Association of Southeast Asian Nations (ASEAN) has been one of the successful cases in terms of regional integration. Since its establishment in 1967, it has had numerous issues to address, from the threat of Communism in the region, regional incidents among member countries, the problem with China regarding the claims of Vietnam, Philippines for the sovereignty of the islands, among others.

ASEAN, likewise, is not alone in its regional integration, since it has signed or is in the process of negotiation, several agreements of an economic nature, especially. From the Free Trade Agreements with China to ASEAN + 6 (ASEAN, China, Japan, South Korea, India, Australia, and New Zealand), as well as the current Regional Comprehensive Economic Partnership (RCEP). Then, the ten countries that makeup ASEAN (Indonesia, Malaysia, Thailand, Singapore, Philippines, Brunei Darussalam, Vietnam, Cambodia, Laos, and Myanmar) have been involved in an attractive international relations dynamic to analyze.

However, a few years ago, a concept has emerged that falls within a broader framework, which confronts large countries. That concept is called Indo-Pacific. Meanwhile, the big countries that are currently confronted in a dispute that hangs over various aspects (geopolitics, military strategy, technology, bilateral trade) are the United States and China.

So, both the United States (and its allies) and China have developed major strategies to have greater competitiveness in the region. ASEAN, being involved in the area from a geographical issue, has not been able to avoid being left out, as it was necessary to have a position, mainly, as a regional bloc. Of course, not all its members have had the same interests, nor have they demonstrated the same dynamic. However, this year ASEAN has ruled on the Indo-Pacific, as it is on this concept that alliances between countries are drawing up as well as political-economic strategies that, whatever their degree, impact on the population. For this reason, this monograph tries to address the position of ASEAN for the other actors, concerning the Indo-Pacific, trying to elucidate what may happen in the future. 
II. ASEAN outlook on the Indo-Pacific: why was that necessary?

Currently, we are witnessing geopolitical challenges and related to this, and there is a concept generating controversy: "Indo-Pacific". When we think about Indo-Pacific, then we realize that is another concept -quite differentfrom the Asia-Pacific. Like the Asia Pacific, or Asia itself, the Indo-Pacific is a tactic for governments to set up the international situation to match their policy goals conditions. But the number of countries that find it a valuable way of understanding the world is increasing. And why is this happening? Because of the importance of this region: it includes the energy supplies, production chains, infrastructure and security networks that connect the Middle East, West Asia, and East Asia. It additionally contains US security and economic relationships throughout the Pacific. Even for Australia, the idea of the IndoPacific works well. Looking to the past, Australia's security, trade, and communications all rolled back through the Indian Ocean to Britain via the British Empire's own 'string of pearls' in Singapore, Colombo, Bombay, Aden and the Suez Canal.

In this context, more countries are participating in the Indo-Pacific, such as India. Historically, the US has been looking for any reason to be present in the Asian scenario. So, with Indo-Pacific in trend, they can be active in their purposes. Let us say it is another reason to fight with China. The IndoPacific region is fascinating if we consider which countries are involved in: it contains significant powers in world politics such as China, US, Japan, India, Russia, Australia, and the ASEAN member states. For ASEAN itself, except Laos, the other nine ASEAN members have maritime resources.

Subsequently, as ASEAN states are in the Indo-Pacific neighbourhood, they can take part in the discussion.

Indo-Pacific, which implies to the region across the Indian as well as Pacific Oceans, has had its initial progress from a long time ago. But Gurpreet Singh Khurana claimed that he was the first one presenting the vocabulary on academic dissertations through his work entitled "Security of Sealines: Prospects for India-Japan Cooperation" in 2007. By the other way, Japanese Prime Minister Shinzo Abe is considering as the first world leader who took up the notion as a cooperative context when he was talking to the Indian parliament in 2007, referring to countries around Asia, Africa, Pacific, as well as Indian Oceans. Those proposals of using the word of 'Indo-Pacific' get more interest with the increase of China through One Belt One Road (OBOR), and then colliding with the US and its allies' interests around the region (Yunanto y Samhudi, 2019). So, the concept of the Indo-Pacific as a regional one is not new to link the Indian and Pacific Oceans, even recognizing at the same time the role of India and Indonesia in any strategic geographical 
interpretation. But the Indo-Pacific concept was "alive" with the US Trump administration's acceptance of it.

Considering this, what is the situation with ASEAN countries? These countries, while belonging to the Association of Southeast Asian Nations (ASEAN), they do not act with the same energy. For example, for Indonesia, this concept of Indo-Pacific has been imported from some time ago. In other words, they were leading and sharing their vision about it.

After some meetings and summits (more than a year of deliberation), ASEAN issued its 'Outlook on the Indo-Pacific' in 34 ASEAN Summit on 23 June 2019 in Bangkok, Thailand. The critical fact is ASEAN members tried to react against the US, India, Japan, and Australia, with its interest in the Indian and the Pacific Ocean. Because they are locating between them, they cannot be out of the game. Now, is the moment to act and react. However, for these Southeast Asian countries, the role in this game is not about a zero-sum game basis, but win-to-win cooperation. So, the confrontation between US' view with China's one is not the way ASEAN want to follow. What is important, anyway, all ASEAN members are committing with this ASEAN view? Or maybe some of them would like to support the significant powers' vision? Think about, for example, historical ties of the Philippines and Thailand with the US, and Cambodia with China. Because of that, there could be such coordination problems if members of this bloc cannot reach agreement on what is the best way or option, even when it is affecting their interest to do so. Before the ASEAN Outlook was released, some Filipino analysts supported the US, because it "presents an opportunity for the Philippines to be part of a loose coalition of states that are willing and able to counter unilateral Chinese behaviour in the SCS [South China Sea] (...)" (Vicedo, 2018, parr. 4). Among other things, because during the 2017 Philippine-US Bilateral Strategic Dialogue, both countries announced their commitment to 'support freedom of navigation and overflight' in the South China Sea. However, the Philippines understands that, while their alliance with the US continue unbroken, at the same time, they foster closer economic ties with Beijing. In the case of Vietnam, they are exploring stronger maritime security and defence industry cooperation with the United States as well as the Vietnam-Japan Joint Vision Statement on Defence Relations and the promotion of Vietnam-Australia security relations into a strategic partnership. For the US, it is essential to note that Vietnam will lead the Chairman at ASEAN from 2020. During the "Meridian Diplomacy Forum: Countries of the Mekong" held in Washington last June, prominent US diplomats had highlighted the importance of Ha Noi for their country. The five states in the Greater Mekong Subregion (GMS), namely Cambodia, Laos, Myanmar, Thailand, and Vietnam are also in the Lower Mekong Initiative (LMI), an Association promoted with the US in 2009 to create integral subregional cooperation. Even that, US diplomats recognize and understand 
ASEAN state members do not want to choose either US or China.

Anyway, the 'Outlook on the Indo-Pacific' focus on 1) maritime cooperation, 2) connectivity, 3) meeting UN sustainable development goals, and 4) economic and technical cooperation. These areas are modern thinking paths to reach peace and prosperity. And this is important to realize, because "ASEAN is no longer the small collection of conservatives, developing, anti-communist, authoritarian states of the Cold War that made consensus easier to forge. Its current members have a range of economic needs, political systems, and strategic considerations" (Ja Ian Chong, 2019, parr. 8). ASEAN identifies the security-economic connections in the current regional contestation. At the same time, they focus on practical economic-development cooperation.

The problems arise when there are different understandings about what Indo-Pacific means for all countries involved. Let us take the example for the United States: two years ago, in its annual National Security Paper, they emphasized that Indo-Pacific region covers from the west coast of India to the western shores of the US. It is broader than Asia-Pacific meaning. Along with Australia, Japan, and India -the "Quad"- they talk about the idea of a "free and open Indo-Pacific". But that is a direct message against China because they see it as a treat to the "rules-based international order" as promoted by the US. The strategy is balancing as China is like the directed revisionist state to the status quo. ASEAN needed to issue about this. In this year, France revealed its Indo-Pacific policy in May 2019, followed by the United States with its updated 'Indo-Pacific Strategy Report' agreeing with US Acting Defense Secretary Patrick Shanahan's speech at the 2019 Shangri-La Dialogue in June.

What is the point for ASEAN? Even though they accept the term "Indo-Pacific", it does not mean that they share the US' vision at all. They do not want to play for any of the major powers. ASEAN also do not want to play for China's game. But ASEAN cannot deny the importance of China for them: for example, considering China is a member of existing regional infrastructure such as the East Asian Summit and the ASEAN Regional Forum (ARF). Apart from these, it is also noting that exist others ASEAN-led mechanisms like the ASEAN Defense Ministers Meeting Plus (ADMM-Plus), the Expanded ASEAN Maritime Forum (EAMF) and the relevant ASEAN Plus One mechanisms.

One point of differentiation between the US and ASEAN views are about the concept of 'freedom'. If one reads the ASEAN Outlook, there is no such explanation about what freedom means. Anyway, one could understand it as linked with the principle of non- intervention, respect for sovereignty, and equality. Looking at the US' view, 'freedom' means freedom to exercise independence as well as freedom from coercion. But, after that, for ASEAN 'freedom' is more about the inter-state relations, based on the international treaties. For the US, it is related to international relations too, but also the 
domestic governance, including the Human Rights.

Now, even is true that there are some worries about China and its ambitious plan in the region, and more concerns when we refer to the South China Sea tensions, even that the relationship between China and Southeast Asia has continued solid. Among other reasons, because China is the ASEAN's top trading partner, the geographical closeness and, significant, the historical/cultural links. So, it is doubtful that ASEAN would decline its cooperation with China (Kamaruddin, 2019). The stable economic development and international trade in China are two fascinating reasons for ASEAN to maintain good relations with them.

Within this context, regional analysts have enthusiastically supported the ASEAN Outlook on the Indo-Pacific. Notwithstanding, they see this as an ASEAN's "act of diplomatic and political assertion" and a "stand against great power rivalry" (Laksmana, 2019, parr. 3). For others, the ASEAN Outlook "is in many aspects the same old wine in a newly packaged bottle." (Hoang Thi Ha, 2019, p. 2).

Issuing a document is not an easy task for ASEAN when we think about China and the US as the big players and confronting with each other. For one side, and under Xi Jinping's rule, China will continue its hegemonic performance as its Belt and Road Initiative (BRI) pursues to offer an alternative regional order. Even Beijing has not been working with the IndoPacific terminology, and one could consider the maritime part of 'Belt and Road Initiative' as "Indo-Pacific with Chinese traits". The engagement of China by introducing BRI, has provoked several different reactions, notably from ASEAN and the US, which is manifesting variations of the Indo-Pacific cooperative agenda. For the other side, the incredible volatility of the Trump administration, including its destructive trade war, has deteriorated the scepticism over Washington's and its plan in the region. So, there is a question ASEAN analyst could do: with this panorama, and if ASEAN is looking for keeping its centrality, are existing mechanisms like the East Asia Summit and the ASEAN Regional Forum enough to contain it?

ASEAN is not looking to replace its existing mechanisms. Still, it is proposing to reestablish ASEAN's agenda of priorities for regional multilateral cooperation.

As the ASEAN Outlook emphasizes on ASEAN community-building and centrality, ASEAN member states decide to stay on ASEAN's view, and not to choose any significant power. So, its member states do not go towards one significant power's plan more than another. Then, by confirming ASEAN's "open door" policy with all partners and countries, they sustain their energies to promote the multi-polarity in the region.

Improving the regional connectivity with institutions like the Indian Ocean Rim Association (IORA), the Bay of Bengal Initiative for Multi-Sectoral 
Technical and Economic Cooperation (BIMSTEC), the Mekong subregional cooperation with ASEAN-led mechanisms could offer a clearer vision for better strategies for ASEAN.

Also, institutionalizing the East Asia Summit (for example, as being renamed the "Indo- Pacific Summit", with a permanent secretariat to reach institutional backing and weight) (Laksmana, 2019). Some authors say that ASEAN should propose the creation of the Master Plan on Indo-Pacific Connectivity (MPIC) - an extension of the Master Plan on ASEAN Connectivity (MPAC). Thus, promoting complementarity, synergy and prevention of overlap and contest in the region (Thepchatree, 2019).

What could happen if ASEAN could also try to help in the region in ways like the former Indonesian Foreign Minister Marty Natalegawa's idea of an "Indo-Pacific Treaty" as well? According to with some analysts, the ASEAN Outlook on the Indo- Pacific is the first step in endorsing "ASEAN centrality'; however, critics appear because the document lays out general principles but not concrete measures for cooperation. Referring to Indonesia, why is it worried about Indo-Pacific? Because it does not like the US' vision of isolating China. Even, they see US' allies as outside powers without ASEAN's participation. So, Indonesia was developing a new, different strategy coherent with ASEAN's principles such as consensus-building, diplomatic and political approach -not to focus so much on military strategy-. Indonesia has been leading the push for ASEAN to declare its vision for the Indo-Pacific: its proposal was being public at a gathering of ASEAN foreign ministers in January 2018. It wants an Indo-Pacific "regional architecture" similar to ASEAN's "ecosystem of peace, stability, and prosperity", which would draw on ASEAN-led mechanisms and based on the principles of inclusion, confidence building and international law. It outlooks the Asia- Pacific and the Indian Ocean regions as tightly integrated and interconnected, describing them as a single geostrategic place. When Indonesia fixes its relations with excellent power relations, it chooses "pragmatic equidistance", that means maintaining strategic autonomy by engaging one high power in cooperation without losing its relationship with another. But, outside of ASEAN, Indonesia does not have enough capacity for geopolitics (Laksmana, 2018).

Some Western analysts critic ASEAN's Outlook because it does not mention China as the target to fight. I agree with someone who can say what happens because it is the way how ASEAN has been doing its business since its establishment in 1967. Therefore, ASEAN destined to disappoint those who would like to find it behave like a high-power fighting with others (Acharya, 2019).

So, ASEAN as a bloc is looking for cooperation, but not competition. The Bangkok Summit underscored improvement in upgrading ASEAN infrastructure projects and highlighted the significance of boosting the 
integration of these infrastructure projects with other countries' ones under the slogan 'connecting the connectivities'. As mentioned before, there are several areas of possible collaboration, but issues like maritime security and connectivity are vital. There are many infrastructure projects in the IndoPacific: ASEAN has the Master Plan on ASEAN Connectivity (MPAC), China has the Belt and Road Initiative (BRI), while Japan, India and the United States are developing their regional infrastructure projects. Regionally, ASEAN could use active mechanisms within the Mekong subregional cooperation structures at a time when China and Japan are contesting with each other to influence in the Mekong. In terms of maritime cooperation in the Indian Ocean region, ASEAN and IORA could work together in exchanging their own experiences in regional collaboration (Hussain, 2019).

The ASEAN Outlook does not want to see the Asia-Pacific and the Indian Ocean as a single geographic structure. Why? Because of the vast diversity in the territories, peoples and their histories, the socio-cultural patterns and international relations are circulating throughout the two oceans. As an Alternative, the ASEAN Outlook views the conjunction between the Asia-Pacific and the Indian Ocean regions from two viewpoints: 1) an area of vibrant economic integration and connectivity, and 2) a unified maritime space. The emphasis on Indo-Pacific concept as an economic and connectivity-linked one (and not related to the military-security one) supports to introduce a neutral and inoffensive ASEAN Indo-Pacific outlook - one that not intended to confront or contain any other country or bloc-. Project performed by ASEAN is believed a hedging tactic to the contestation of power in the region between China and the US. This idea is meant mainly for China because Beijing considers that the Indo-Pacific strategy targeted to limit China's rise.

The ASEAN Outlook development-focused concept has something of the influence of Indonesia's pragmatist foreign policy under the Jokowi administration. Hoang Thi Ha brings refer to this as follow:

A good metaphor of this pragmatism is the coconut deal that sells Indonesian coconuts in Aceh to India's Andaman and Nicobar Islands at low costs thanks to geographic proximity between the islands. Dr Siswo Pramono from the Indonesian Ministry of Foreign Affairs saw this deal as a concrete manifestation of the ASEAN Indo-Pacific outlook: 'This is the Indo-Pacific concept that we mean. It is directly felt by the people. It is not about who wants to contain whom'. (Hoang Thi Ha, 2019)

ASEAN Outlook on the Indo-Pacific is looking to provide the preservation of peace, freedom, and prosperity. ASEAN Outlook on the IndoPacific follows these principles: ASEAN Centrality, openness, transparency, 
and inclusivity. Also, a rules-based framework, good governance, respect for sovereignty, non-intervention, and respect for international law. These laws are coming from UN Charter, the 1982 UN Convention on the Law of the Sea, and other relevant UN treaties and conventions, the ASEAN Charter and various ASEAN treaties (like the ASEAN Economic Community Blueprint, ASEAN Political-Security Community Blueprint, and ASEAN Socio-Cultural Blueprint) and agreements and the EAS Principles for Mutually Beneficial Relations (2011) (Association of Southeast Asian Nations, 2019). In the long run, the ASEAN's vision is the most inclusive yet and signifies an effective option that can stabilize the regional balance of power. For example, if ASEAN could institutionalize the EAS (Laksmana, 2018). So far, there is a substantial agreement that the East Asia Summit is the best stage to talk about the Indo-Pacific. Since 2005, the EAS has been the only site for ASEAN leaders to discuss strategic affairs with their partners from the US, China, Russia, Japan, South Korea, India, Australia, and New Zealand (Chongkittavorn, 2018).

If analyzing the ASEAN Outlook by itself is not good enough, then it is more interesting to compare it with those coming from China, India, and the United States. For example, China's New Security Concept (from 2002), which is a call for the diversification of security to make it inclusive and equitable for all, and it seeks settlement of disputes with its neighbours through peaceful negotiation. However, some analysts say that China's approach for regional architectures in Asia is limited, dictatorial, and unfair. Beijing has seen as seeking the upper hand during talks with smaller parties (for instance, presenting the Belt and Road Initiative (BRI) as a win-win venture but pushing countries into a debt-for-equity swap).

In the case of India, there is a push for an Open and Inclusive IndoPacific. It is clear from a few official Indian declarations that New Delhi wants a free, open, and inclusive maritime agenda in the region. India has stressed the position of ASEAN centrality in any regional architecture in the Indo-Pacific. Both ASEAN and India gave significance to existing norms and internationally accepted rules of law when it linked to freedom of navigation, for example. About US., the Trump administration sees Asia as a military and economic partner against "strategic competitor" China and its policies in the IndoPacific are related to that. And this is no less important: the renaming of the Pacific Command to the Indo-Pacific Command emphasizes that the United States sees the waters of the Indian and Pacific Oceans as only one zone of influence (Bhatt, 2019). In its new Indo- Pacific strategy, the United States places a strong significance in working with India to preserve a free and open Asian region. While India's economic potential and democratic principles are essential to the strategy, it is the potential of defence cooperation that is vital to attaining this vision (Abercrombie, 2018). So, the US put more emphasis on 
security and defence. And for India, is about the protection of its territorial interests in its maritime surrounds.

The significant protagonists behind the 'free and open Indo-Pacific' (FOIP) concept are continuing diplomatic attempts to crystallize a plan for its fulfilment. But there is no agreement on what the idea will involve nor is sure what kind of structures are necessary for its execution. The United States, Japan, and India held their first trilateral meeting on the sidelines of the December 2018 G20 summit in Buenos Aires. They arranged that a 'free, open, inclusive and rules-based' order is vital for peace and prosperity in the Indo-Pacific. To Japan, the FOIP is open to all countries that adhere to the rule of law, freedom of navigation and appropriate principles of transparency and sustainable development. For Japanese Prime Minister Shinzo Abe, his target is to make sure that China and its 'Chinese standards' do not control the infrastructure networks through Asia to Africa. Japan and India have already decided to strengthen naval and maritime security cooperation and join forces on infrastructure projects in third countries, including Myanmar, Bangladesh, and Sri Lanka, to boost strategic connectivity in the Indo-Pacific (Hussain, 2019).

One interesting topic related to the Indo-Pacific arena and its impact on ASEAN bloc in general, and ASEAN member states, could be the monthlong, two-yearly Rim of the Pacific (RIMPAC) exercise, not so far from the Hawaiian Islands. RIMPAC has been a constant since 1971, but the training has evolved, showing fluctuating times and tensions. In many ways, modern RIMPACs are soft power events intended to showcase the attraction of the US as a collaborator and partner. The US emphasizes that many navies would like to train with them. By the other side, significant nations like China and Russia don't offer any invitation to others to their most critical naval exercises. In 2018, Vietnam was joining the activity for the first time. In the case of Malaysia, already participating last time, it was sending a warship for the first time. Something similar was happening with the Philippines (Layton, 2018).

About countries like India and Indonesia, the authors asked if it could be a chance for both countries to reach a common understanding of IndoPacific. But they usually say that this is doubtful, due to a misalignment between the two countries' political and economic targets. India's integration with the Pacific region was to be driven by the 'Look East' policy and then the 'Act East' policy, with focus on regional and sub- regional ideas for trade, economic cooperation, and connectivity. For example, free trade agreements have been signed or negotiated between India and the Association of Southeast Asian Nations (ASEAN), Thailand, Malaysia, and Australia. However, in general, the results of these initiatives have been limited. Now, India has declined to pull out of the Regional Comprehensive Economic Partnership (RCEP). Deep-rooted structural local problems, weak global demand and 
increasing protectionist sentiment amongst potential trading partners could explain why that happened. India's stances on agriculture and services have also impeded RCEP negotiations.

About Indonesia, its integration with the Indian Ocean region stretches back to the founding of the Indian Ocean Rim Association (IORA) in 1997 and has been boosted by its commitment with the Indo-Pacific concept since 2013. The current government of Joko Widodo foresees Indonesia as a maritime pivot. Indonesia is interested with the Indian Ocean because of the Middle Eastern energy, and India's possibility as both an investor and a market for Indonesian goods. During Indonesia's 2016-18 leadership of IORA, there was a calling for more significant intra-regional trade and investment.

Nevertheless, Indonesia's commitment to Indian Ocean markets continues limited. And we refer bilaterally to Indonesia and India, protectionist attitudes remain to hinder a developing of India-Indonesia trade. Under Widodo administration, Indonesia's international agenda influenced by the requirement for foreign investment. For Widodo, now the Indian Ocean region and the broader Indo-Pacific are only of significance for his economic plan. Anyway, Indo-Pacific is a concept being progressively utilized by both policymakers and analysts under the theory that commercial links between Asia's two oceanic regions will go on to expand as much as economies of countries like India and Indonesia will continue growing (Chacko, 2018).

Following Gyngell, sometimes the Indo-Pacific bodies will be created to cooperate (the East Asia Summit), and at times they will be intended to compete (the evolving infrastructure options to the Belt and Road Initiative). Finally, he says "Only a strategic and economic ecosystem as varied as this will be able to accommodate the Indo-Pacific's diverse faces" (Gyngell, 2018, párr. 20).

\section{Conclusion}

ASEAN has taken part in the development of the INDO-PACIFIC concept. After several meetings, where it was necessary to find a point of a joint agreement, they finally arrived at what is known as ASEAN OUTLOOK ON THE INDO-PACIFIC. This Outlook also understood as a stance against those of the great powers (mainly, the United States and China).

ASEAN does not want to favour the positions of the great powers but has chosen its vision: ASEAN WAY. In it, the focus is on non-interference in internal state affairs, the principle of sovereignty, economic cooperation, among other issues.

Even so, it is not clear how the links between the different parties will develop, that is, how the different positions can find an echo in the same place. Therefore, it is necessary establishing an Institution that deals specifically with 
Indo-Pacific, in which all the actors in the region are part. Or institutionalize or formalize much more the East Asia Summit, recognizing its progress achieved so far.

ASEAN, with its mechanisms and Treaties, cannot in itself address the issue. It needs the approach and cooperation with everyone else. That will not be easy considering the current regional and international context, characterized by the tension between the United States and China. Among them, ASEAN is in the middle.

\section{Bibliographical references}

Abercrombie, C. (20 May 2018). Translating defence trade into cooperation in the Indo-Pacific. East Asian Forum.

https://www.eastasiaforum.org/2018/05/20/translating-defence-

trade-into-cooperation-in-the-indo-pacific/

ACHARYA, A. (11 August 2019). Why ASEAN's Indo-Pacific outlook matters. East Asian Forum.

https://www.eastasiaforum.org/?p=198717?utm_source=newsletter\& utm_medium=email\&utm_campaign=newsletter2019-08-11

BнAтт, P. (31 July 2019). ASEAN's Outlook for the Indo-Pacific: An attempt to set rules of the game. South Asian Voices.

https://southasianvoices.org/aseans- outlook-for-the-indo-pacific-anattempt-to-set-rules-of-the-game/

CHAckO, P. (30 August 2018). Far from all-in on the Indo-Pacific. East Asian Forum. https://www.eastasiaforum.org/2018/08/30/far-from-all-inon-the-indo-

pacific/?utm_source=newsletter\&utm_medium=email\&utm_campaign

=new sletter2018-09-02

Chongkittavorn, K. (4 December 2018). Watch out for Asean's new IndoPacific. Bangkok Post.

https://www.bangkokpost.com/opinion/opinion/1587206/watch-

out-for- aseans-new-indo-pacific

GyNGELL., A. (23 May 2018). To each their own 'Indo-Pacific'. East Asian

Forum. https://www.eastasiaforum.org/2018/05/23/to-each-theirown-indo-pacific/

HoANG THI HA (2019). ASEAN Outlook on the Indo-Pacific: Old Wine in New Bottle? Perspective, ISEAS Yusof Ishak Institute, Issue 2019, N 51, ISSN 2335-6677, 2-7. https://www.iseas.edu.sg/images/pdf/ISEAS_Perspective_2019_51.p df

Hussain, N. (16 August 2019). ASEAN joins the Indo-Pacific conversation. East Asian Forum. https://www.eastasiaforum.org/2019/08/16/asean- 
joins-the-indo-pacific-conversation/

Hussain., N. (9 February 2019). Regional consensus needed for a 'free and open Indo-Pacific'. East Asian Forum.

https://www.eastasiaforum.org/2019/02/09/regional-consensusneeded-for-a-free-and-open-indo-pacific/

JA IAN CHONG (3 September 2019). ASEAN needs more than an 'outlook' on the Indo- Pacific. East Asian Forum. https://www.eastasiaforum.org/2019/09/03/asean-needs-more-thanan-outlook-on-the-indo-pacific/

KAMARUdDin, N. (5 August 2019). ASEAN's strategic engagement in the unwieldy Indo-Pacific. Lowy Institute. https://www.lowyinstitute.org/the-interpreter/asean-s-strategicengagement-unwieldy-indo-pacific

LAKSMANA, E. (27 November 2018). Buck-passing from behind: Indonesia's foreign policy and the Indo-Pacific. Brooking. https://www.brookings.edu/blog/order-fromchaos/2018/11/27/buck-passing-from-behind-indonesias-foreignpolicy-and-the-indo-pacific/

LaKsmana, E. (19 September 2019). Flawed Assumptions: Why the ASEAN Outlook on the Indo-Pacific is Defective. Asia Global Online. https://www.asiaglobalonline.hku.hk/flawed-assumptions-why-theasean-outlook-on-the-indo-pacific-is-defective

LAKSMANA, E. (20 November 2018). Indonesia's Indo-Pacific vision is a call for Asean to stick together instead of picking sides. South China Morning Post.https://www.scmp.com/weekasia/geopolitics/article/2173934/in donesias-indo-pacific-vision-call-asean-stick-together

LAYTON, P. (2 July 2018). Mai Tai diplomacy in the Indo-Pacific. Lony Institute. https://www.lowyinstitute.org/the-interpreter/mai-tai-diplomacy-inthe-indo-pacific

ThePChAtree, P. (15 August 2019) Expanding ASEAN's Indo-Pacific role. East Asian

Forum. https://www.eastasiaforum.org/2019/08/15/expanding-aseans-indopacific-role/

Vicedo, C. (2 August 2018), The Philippines stays free and open in its position on the Indo-Pacific. East Asian Forum. https://www.eastasiaforum.org/2018/08/02/the-philippines-staysfree-and-open-in-its-position-on-the-indo-pacific/

YunANTO, S. y SAMHUdi, G. R. (2019). Different interests explain different proposals: The contestation of Indo-Pacific cooperation framework between ASEAN and the US, E-Journal GLOBAL STRATEGIS, Vol 13, $\mathrm{N}^{\circ}$ 2, 2019, UNIVERSITAS AIRLANGGA. https://ejournal.unair.ac.id/JGS/article/view/12299/8674 
Comité de ASEAN en Buenos Aires

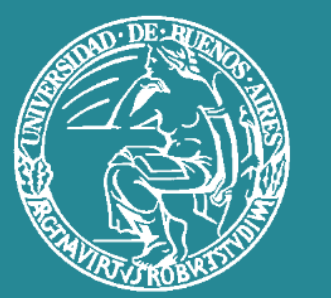

Grupo de Estudios sobre Asia y América Latina Instituto de Estudios de América Latina y el Caribe Universidad de Buenos Aires 